\title{
Intersectoral Competition for Water Between Users and Uses in Tamil Nadu-India
}

\author{
S. Suresh* \\ Department of Civil Engineering, Sona College of Technology, Salem, India
}

Water is a manageable asset for drinking, food creation, and industry, and demand increases as the population increases. Water for irrigated agriculture, industry and domestic needs in India will go up to 1,072, 130, and 102 billion $\mathrm{m}^{3}$ (BCM) by the year 2050. In the state of Tamil Nadu in 2025, water needs for irrigation, domestic, livestock, and industrial sectors will be $52.7,1.5,1$, and 2 billion $\mathrm{m}^{3}$, respectively, against the available supply of 24.6 BCM of surface water and $23 \mathrm{BCM}$ of groundwater during the same period. A balance between need and supply is often difficult to achieve. By the year 2050, some 60 per cent of the world's population will live in cities. In India and Tamil Nadu, 38 and 48 per cent of people will live in cities. Tamil Nadu is the second most urbanized state in India with 48 per cent of its population living in cities. This urban push will demand a large share of common water resources and most of the reservoir systems will face increased water demand for non-agricultural purposes, bringing in imbalances with other sectors, namely agriculture. Contrary to mounting demand, it will be difficult to facilitate the growing need for water. Furthermore, there are social and environmental costs in terms of the diversion of water from agriculture to urban uses. The discharge of sewage and industrial effluents also pollutes surface and groundwater, affecting not only human health but also the entire ecosystem. This paper examines the water management challenges in Tamil Nadu, India with respect to meeting future water demands across competing sectors.

Keywords: intersectoral competition, ground water, anicut, river basin, fresh water

a section of the journal

Frontiers in Earth Science

Received: 02 February 2021

Accepted: 30 June 2021

Published: 08 September 2021

Citation:

Suresh S (2021) Intersectoral Competition for Water Between Users and Uses in Tamil Nadu-India.

Front. Earth Sci. 9:663198. doi: 10.3389/feart.2021.663198 


\section{INTRODUCTION}

The Indian irrigation sector utilizes about ninety-three percent of total water withdrawn and the remaining seven percent is shared between domestic and industrial sectors. At the time of Indian independence (1947), the irrigation facilities available were one-sixth of the cropped area. The government's main concern was to expand the irrigation infrastructure. Reservoirs, barrages, and diversion structures were constructed without thinking about environmental issues. In the late seventies, the importance of ecological balance was realized and attention turned to improving the performance of existing systems. In the eighties, it focused on institutional and social constraints. By 1987, a National Water Policy of India (NWP) was formulated and provided guidelines for acquiring, conserving, and utilizing water resources and the need to ensure equity and equality. The policy recommends the involvement of farmers in irrigation management. At the beginning of the 21 st century, it was thought that the integrated land, water, and human resource management

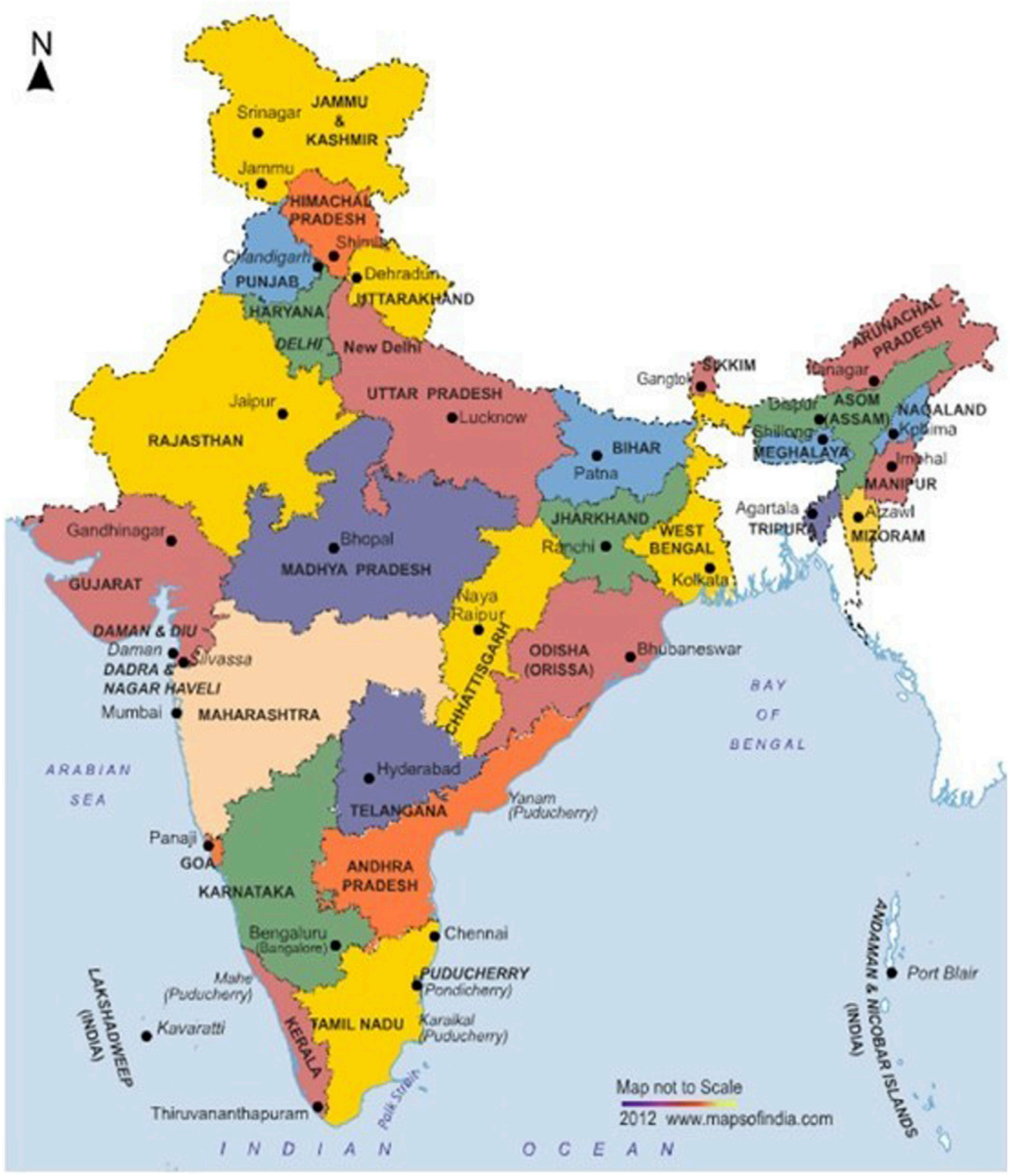

FIGURE 1 | Location map of Tamil Nadu State. Source: Maps of India. 
was ideal for sustainable development and safeguarding the water resources for the future generation.

Tamil Nadu is the southernmost state of India, delimited by the Indian Ocean on the south, the Bay of Bengal to the east, and on the west, north, and east by the states of Kerala, Karnataka, and Andhra Pradesh, respectively (Figure 1). With a spatial extent of $1,30,058 \mathrm{~km}^{2}$, this state covers 4 percent of the total area of India, 7 percent of the population of India, and 3 percent of the water resources of India (Census of India 2011). Tamil Nadu has a fairly high average population density of 429 per $\mathrm{km}^{2}$ and is also the second most urbanized state of India with $48.45 \%$ of the population living in urban areas (Chitra and Laxmi, 2017). The state has a tropical climate with a temperature of $43^{\circ} \mathrm{C}$ in summer and a minimum of a little lower than $18^{\circ} \mathrm{C}$ during winter (Statistical Hand Book 2016-2017). The average rainfall of the state is $925 \mathrm{~mm}$ against the average rainfall of $1,170 \mathrm{~mm}$ in India. Tamil Nadu receives its rainfall from the north east as well as south west monsoons. A variation in the monsoon has a serious impact on the economic life and livelihood hood of people, especially in rural areas. Thus, Tamil Nadu is a deficit state from the point of view of water resources both for irrigation and drinking water and is dependent on the monsoons very heavily.

The intersectoral competition for water between the users and uses involves varied resources, including 1) water, 2) land, 3) human, and 4) livestock. Thus, integrated water, land, human, and livestock resources management is necessary to avoid conflicts and ensure rational and sustainable utilization of water resources. Tamil Nadu is one of the more progressive states in India, and has already achieved more than 95 per cent of its total water potential, and has implemented several inter- and intra-state water transfer diversions from existing irrigation projects (the water transfer from Veeranam tank to Chennai city by a $250 \mathrm{KM}$ pipeline is the second longest ever and the longest intra state transfer in India (DFID, 2005)). Tamil Nadu also undertakes ground water extraction, desalination of sea water, and cloud seeding, etc., to augment water for domestic sectors. The crux of the entire problem lies in the successful implementation and successive follow-up. A host of other factors are responsible for non-implementation or improper implementation of meeting the water requirement. These include a lack of coordination, unimodal, multiple jurisdictions, mutual exclusiveness, and political motivations. Vairavamoorthy et al. (2007) outline guidelines for the design of the urban water distribution systems, especially developing countries with equitable distribution when the resources are scarce.

A climate crop water requirement (CCWR) integrated framework (Mohan and Ramsundram, 2014) has been developed. The project studied the influence of climate variability on irrigation water requirements in an arid region, the Manimuthar river basin in India, and found that the irrigation water requirement is likely to increase by $5 \%$ in the time period from 2010 to 2020. Bitterman et al. (2016) present a conceptual framework for measuring water security in the context of rainwater harvesting tanks. Glendenning et al. (2012) focus on the hydrological impact of rainwater harvesting (RWH) on the ground water recharge in rural areas of India and emphasize remote sensing methods and modeling for better assessment and policy to RWH. Sivasankar et al. (2012) studied the various physical and chemical characteristics of groundwater samples from Ramanathapuram, a coastal district of Tamil Nadu, and the aquifer are severely affected, with a fluoride content more than $1.5 \mathrm{mg} / \mathrm{L}$. Therefore, this paper investigates the various water management challenges in Tamil Nadu, India with respect to meeting future water demands across competing sectors.

\section{WATER RESOURCES OF TAMIL NADU}

\section{Major Surface Water Resources}

The state is drained by 34 river basins with about 54 major reservoirs and more than 300 medium and small anicuts, barrages, and diversion structures. Construction of dams, diversion structures, and barrages are centuries old. The Grand Anicut (called Kallanai in Tamil, kall = stone: Anai $=$ dam) was constructed by the chola dynasty of King Karikalan during the second century BC. It is possibly the oldest existing structure on earth still in operation. At present, for convenience, the 34 river basins are grouped into 17 major river basins (Figure-2). Thus, almost 95 percent of the surface water potential is brought into human control by way of the construction of dams and anicuts. While major dams were constructed during British rule, medium projects were commissioned after independence. Most of the major rivers like Cauvery, Pennar, Palar are interstate rivers (Figure 2) and their flows in the state are dependent on certain mutual agreements with the neighboring states like Karnataka, Andhra Pradesh, and Kerala. Rivers are state subjects and therefore there are often disputes about sharing waters between the states. This problem is further aggravated when the political party in power in a state is different from the party that rules at the center. Moreover, since states have been divided on a linguistic basis, there are a number of reasons for disagreement.

\section{Groundwater Resources}

Having utilized more than $90 \%$ of the available surface water resources, it is necessary for Tamil Nadu to develop its own groundwater resources, including a more judicious conjunctive use of its own surface and groundwater. The groundwater estimation committee (GWEC) constituted by the National Bank for Agriculture and Rural Development (NABARD) with the Central Ground Water Board (CGWB, 2000) and Groundwater wing of the public works department (PWD), estimated that the groundwater potential in Tamil Nadu is $22,432 \mathrm{Mm}^{3}$, of which $1,022 \mathrm{Mm}^{3}$ is earmarked for domestic and industrial water supply requirements (CGWB 2017). The actual requirement of water supply schemes is $1,057 \mathrm{Mm}^{3}$ both for the urban and rural populations. However, these figures, although indicative of the overall water balance, should be taken with a great deal of caution, particularly as regards domestic water supply where spot-specific availability is as critical as sheer availability. At present, only $61 \%$ of the groundwater has been harnessed and it is still the most economical, individually managed (private) resource. Traditionally well irrigation was practiced in the eastern part 


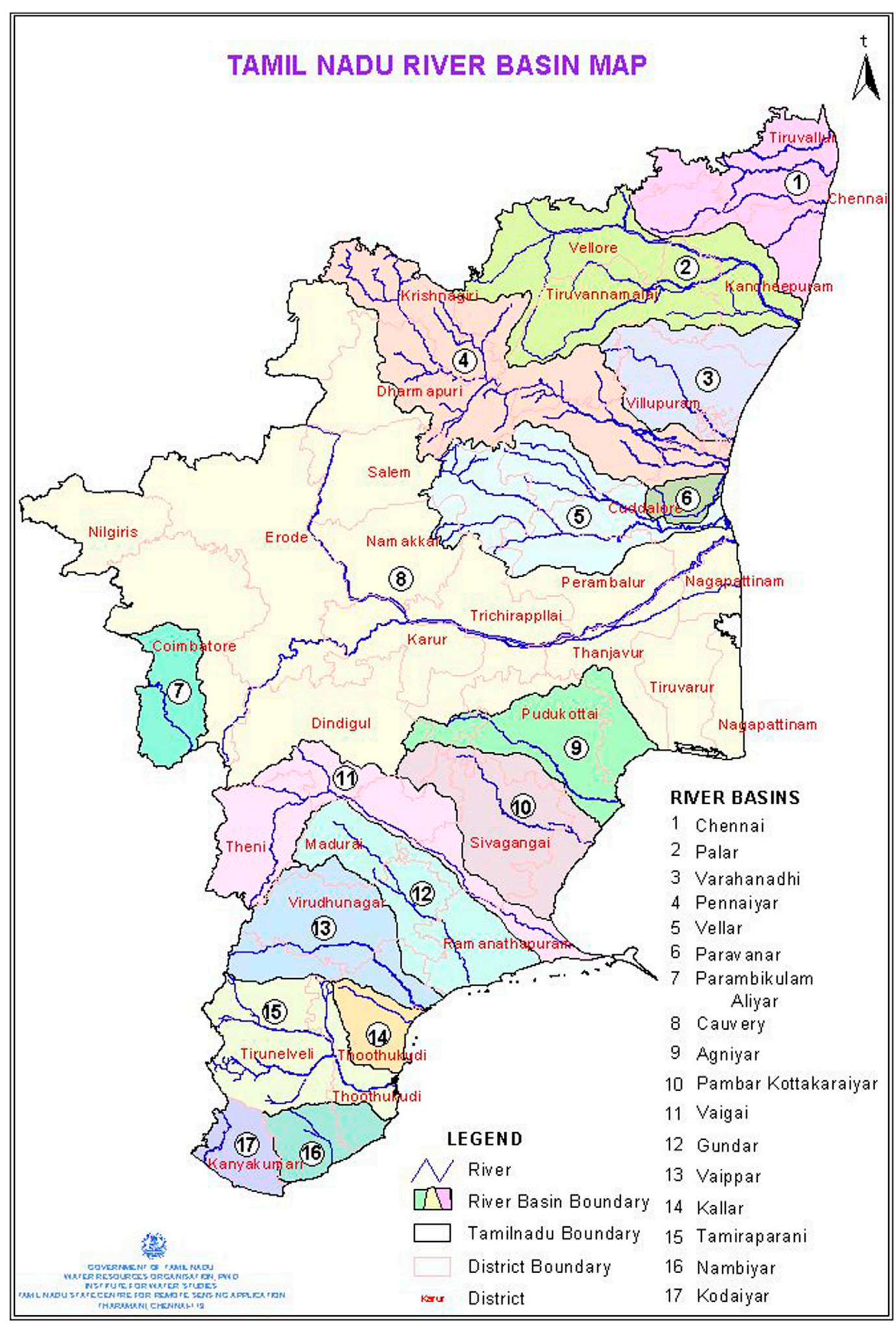

FIGURE 2 | River basin of Tamil Nadu. Source: PWD, Chennai, Tamil Nadu. 
of the state. There were open wells and the water was drawn by draught powered by bullocks. The depth and drawing of groundwater are directly related to the length and duration of travel by the bullocks, which helped in sustaining the groundwater without depriving groundwater from neighbors. The advent of electrification and use of high-powered pump sets, improvements in drilling technology, and the subsequent supply of free electricity for agricultural uses had led to the largescale mining of groundwater, leading to dwindling quantities and deteriorating quality. It should be understood that the availability of an irreproachable standard constitutes part of the very quality of human life. The difficulties and cost of treating polluted water and the impossibility, even in the medium term, of rehabilitating polluted groundwater systems should encourage us to understand the vital need for maintaining good quality groundwater resources. The overexploitation of groundwater beyond the annual recharge into aquifers has already led to this resource being classified as exploited (CGWB 2017).

From the Table 1 it can be observed that 23 percent of total blocks experience heavy groundwater extraction, over and above the recharge, resulting in depletion and seawater ingress in the coastal aquifer system. By adapting spot-specific artificial groundwater recharge techniques continuously for more than a decade in Tamil Nadu, it is possible to recharge 3 and $4 \mathrm{~m}$ thick sedimentary and hard rock terrains aquifers, respectively, and additionally, recharge about 375 TMC (Thousand Million Cubic feet) of groundwater.

TABLE 1 | Groundwater exploitation level in Tamil Nadu. Source: CGWB 2017.

\begin{tabular}{llcc}
\hline S. No & Classification & Exploitation level & No of blocks \\
\hline 1 & Dark & $85-100 \%$ & 89 \\
2 & Grey & $65-85 \%$ & 86 \\
3 & White & Less than $65 \%$ & 211 \\
\hline
\end{tabular}

Total Number of Blocks in 386

Tamil Nadu

\section{DEMAND FOR WATER}

The demand pattern of water among the various sectors (agriculture, industrial, and domestic) has changed (Figure 3) considerably over the past 100 years. For instance, in 2010 out of the total water supplied, $90 \%$ was utilized in the irrigation sector as compared to $6 \%$ in industry and $4 \%$ in the domestic water sector (Natarajan et al., 2017). In 2020, the water utilized by the irrigation sector reduced to $60 \%$ whereas the water diverted to the industrial sector was 26\%, and in the domestic sector $14 \%$. Figure 4 represents water demand in Tamil Nadu for 2010, 2020, and includes the projection for 2025 to 2050 (PWD, Chennai, India).

\section{Agricultural Sector}

India tops the list of countries with a large extent of the area brought under irrigation (total gross irrigated area of $62 \mathrm{MHA}$ ) (ICID, 2018). The state of Tamil Nadu with its limited resources ranks sixth in India and irrigates about 3.5 MHA (State of Indian Agriculture, 2016). By 2022 the total potential created under major and medium irrigation projects is reported at $1.34 \mathrm{MHA}$ ( $90 \%$ of the assessed ultimate potential of $1.5 \mathrm{MHA}$ ) and minor irrigation potential of $2.20 \mathrm{MHA}$ ( $91 \%$ of the ultimate potential of 2.4 MHA). The net sown area accounts for $42.6 \%$ of the total geographical area of which the net and gross irrigated areas as per the recent statistics were of the order of 2.4 and 2.9 MHA, respectively. It is estimated that rice crop consumes more than $45 \%$ of the total water that goes into agriculture. The major sources for irrigation are canals/rivers, tanks, and groundwater. The traditional utilization pattern of the water resources was one third each from reservoirs, tanks, and groundwater. Recently, the pattern transformed and the utilization at present is around 30 percent of reservoir water, 20 percent of tank water, and 50 percent of groundwater, respectively. Agriculture performance (Ruttan 1965; Gollin et al., 2002) is fundamental to India's future economic and social development. Agriculture contributes $30 \%$ of GDP, $60 \%$ of employment, and is the primary source of livelihood in rural areas, which account for $75 \%$ of India's

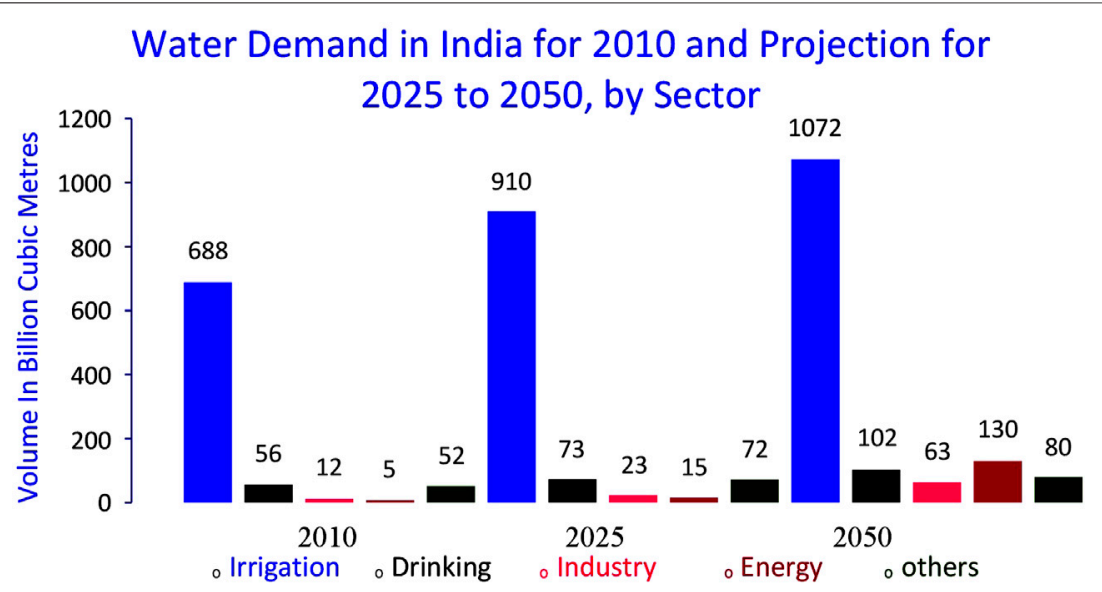

FIGURE 3 | Water demand in India for 2010 and the projection for 2025 to 2050, by Sector. Source: Ministry of Water Resources, India. 


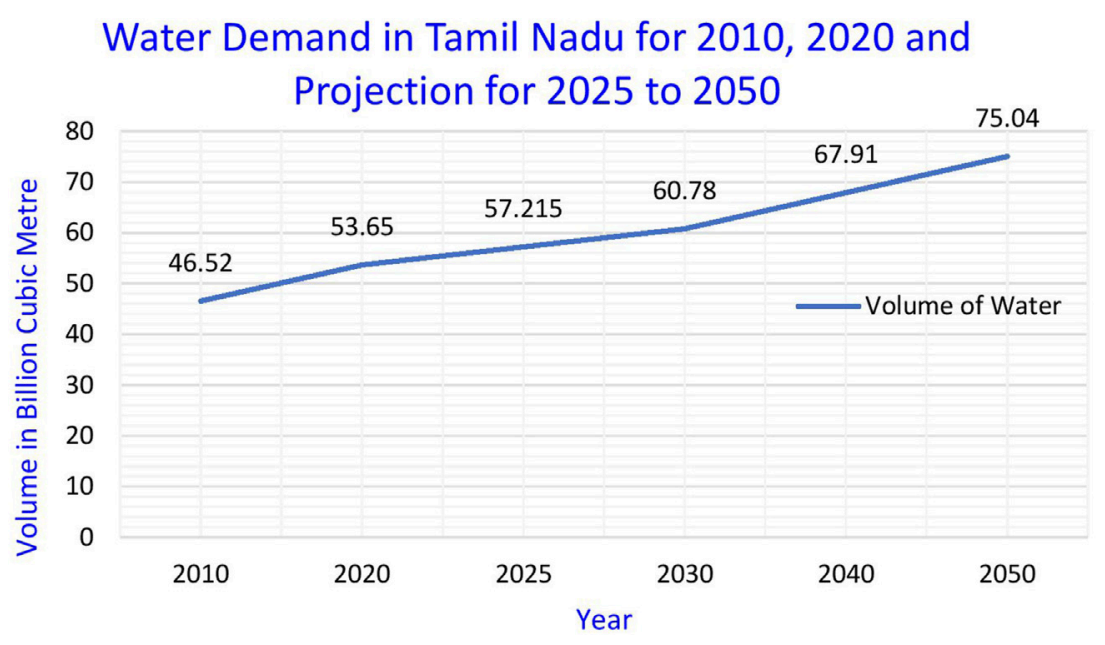

FIGURE 4 | Water demand in Tamil Nadu for 2010, 2020, and the projection for 2025 to 2050. Source: PWD, Chennai, India.

population and $80 \%$ of its poor and low-income population. The performance of irrigated agriculture, which contributes $55 \%$ of agricultural output, will be the most important influence on these objectives. Therefore, the largest irrigated area in the world is in India (ICID, 2018).

\section{Domestic Water Sectors}

There are 146 Municipalities and 15 Municipal Corporations in Tamil Nadu (Corporation of Tamil Nadu, 2020; Municipality of Tamil Nadu 2020). The metro water and the Tamil Nadu Water supply and Drainage Board (TWAD Board) are responsible for providing drinking water to the city of Chennai and the rest of the state, respectively. The drinking water requirement by the total population of Tamil Nadu by 2020 A.D is only $4.5 \%\left(1,055 \mathrm{Mm}^{3}\right.$ both for urban and rural population) of the total assessed groundwater resource, but every year the city of Chennai and most other towns face acute water scarcity (Vairavamoorthy et al., 2007). As the population has grown, freshwater (IPCC et al., 2014) has become increasingly less available where and when it is needed. Acute water shortages already have required extraordinary measures in Chennai, where water was transported from neighboring places by all modes of transport ranging from bicycles and trucks to railway tankers, with distances ranging from a few kilometers to $200 \mathrm{~km}$. In certain parts of the city, people are forced to pay water tax and water charges to the government and at the same time, make daily purchases of drinking water from private vendors for drinking purposes.

\section{Industrial Water Sectors Industry in Tamil Nadu}

Tamil Nadu is the second-largest state economy following Maharashtra state, which has a much larger area and population. Tamil Nadu is also ranked first among Indian states in terms of exports from the special economic zone. Vision Tamil Nadu 2023 anticipates that an investment of 230 billion United States dollars (Rs. 15 lakhs core) will be invested in the state before the year 2023 (ENVIS 2020). This includes investment in projects falling under the manufacturing, infrastructure, and services sectors. At present, out of 217 infrastructure projects listed in vision Tamil Nadu 2023, 88 projects are under various stages of implementation, with the implementation of the remaining projects, the milestones envisaged in vision Tamil Nadu 2023 will be achieved.

Tamil Nadu Industrial Investment Corporation Ltd. (TIIC) is the first state-level financial corporation in the country catering to the needs of MSMEs. TIIC provides financial support to major industrial units such as the sugar, cement, textile, and aluminum industries. TIIC also has a role in the promotion of industrial clusters like hosiery in Tirupur textiles and foundries in Coimbatore, Sericulture and Sago factory in Salam and Dharmapuri, wind mills in Tirunelveli, Palladam, and Udumalper, etc. The major industries in Tamil Nadu are information technology, manufacturing, and engineering industry, automobile industry, leather industry, paper industry, chemical, and plastic industry, textile industry, handloom and power loom industry, sugar industry, and chemical industry.

\section{Industrial Water Demand}

In Tamil Nadu, industry is the second-highest consumer of water. Groundwater has emerged as a preferred source to meet the water requirement of industries since the surface water supply from municipal sources is not sufficiently guaranteed. The industrial water demand of Tamil Nadu has been increasing with the pace of industrial development. Furthermore, the growth of waterintensive industries is constantly putting pressure on the industrial demand for water, while the annual growth of the chemical and construction industry is been 8 percent, the textile and food industry is 6 percent, and the paper industry is 4 percent.

\section{Quantity Dimension}

In India, there are no accurate estimates of water consumption by the industrial sector, but different agencies are recommending the 
water use value. For instance, according to the Ministry of Water Resources, India, the industrial sector accounts for six percent of the total freshwater abstraction while the Central Pollution Control Board (CPCB) recommends 8 percent (Suresh and Surender, 2011). However, the world bank estimates that the current industrial use in India is about 13 percent of the total freshwater withdrawal in the country and predicts the water demand for industrial uses and energy production will grow at a rate of 4.2 percent per year in coming years. The estimates of sectoral water demand in Tamil Nadu are given in Table 2. The industrial water demand in the city of Chennai is estimated at around 326 Mld. These estimates reveal that the industrial water demand is not negligible and will constantly grow in the coming years.

\section{COMPETITION AMONG USER SECTORS}

Rising demand for urban and industrial water supplies poses a serious threat to irrigated agriculture. Irrigated agriculture faces two significant challenges, water shortages and dwindling financial resources, in the coming decades. In India, irrigation investments in the past amount to about $30 \%$ of total public investments after independence. In Tamil $\mathrm{Nadu}$, irrigation projects have taken 18 percent of total/agricultural investments. The investment pattern of plan outlays for the

\begin{tabular}{lcccccc}
\hline TABLE 2 | Estimates of sectoral water demand in Tamil Nadu, India. \\
\hline \multirow{7}{*}{ Category } & $\mathbf{2 0 1 0}$ & $\mathbf{2 0 2 0}$ & $\mathbf{2 0 2 5}$ & $\mathbf{2 0 3 0}$ & $\mathbf{2 0 4 0}$ & $\mathbf{2 0 5 0}$ \\
\cline { 2 - 7 } & \multicolumn{5}{c}{ Volume in billion cubic meters } & $\mathbf{( B C M )}$ \\
\hline Irrigation & 43.22 & 49.85 & 52.7 & 55.78 & 60.44 & 65.6 \\
Domestic & 1.0 & 1.2 & 1.5 & 2 & 3 & 4 \\
Industry & 1.5 & 1.7 & 2 & 2.5 & 3.5 & 4.5 \\
Live stocks & 0.8 & 0.9 & 1.015 & 1 & 0.97 & 0.94 \\
Total & 46.52 & 53.65 & 57.215 & 60.78 & 67.91 & 75.04
\end{tabular}

irrigation sector in India during 2020-21 was 230 million and it rose to 275 million during 2029-30 but the percentage allocation for the same period was 18 and 16 percent, respectively. Despite these challenges, irrigated agriculture will provide 70 to 75 percent of additional food grain requirements to developing countries. This will not be possible without 1) substantial improvements in the productivity of existing irrigation schemes, and 2) investment in new irrigation projects.

\section{WATER DEMAND AND SUPPLY PROJECTIONS}

\section{Population Trends and Explosive Urban Growth}

The population of Tamil Nadu as per the 2011 census is 72.1 million (Census of India 2011) and the total population is expected to reach 85 million in the year 2021AD, out of which 32 million comprise the urban population and 53 million comprise the rural population (Figure 5). On a happy note, the substantial decline in the birth rate could fall further during the coming years. It was 28 per 1,000 during 2012 and 19.2 in 2022 and is expected to reach 15 per 1,000 during the year 2032. The water demand and supply projections have been made for agriculture, domestic, industrial and livestock requirements basin wise (as it would be an appropriate unit for planning any water resources system). For agriculture demand the cropping pattern, area sown, and water requirements are taken into account. For domestic purposes, the existing population in urban areas with a supply of $90 \mathrm{~L}$ per capita per day (lpcd) and rural with a supply of $40 \mathrm{~L}$ per capita per day has been taken (National Water Mission 2017). For industrial consumption, the yardstick fixed by the industries department is taken into account and for the livestock the number of cattle on each river basin is taken and an average consumption of $80 \mathrm{~L}$ per capita per day per cattle. The projection for future requirements for agriculture is made based on future schemes to be implemented in the river basins. For the assessment of domestic water supply, the population projections have been

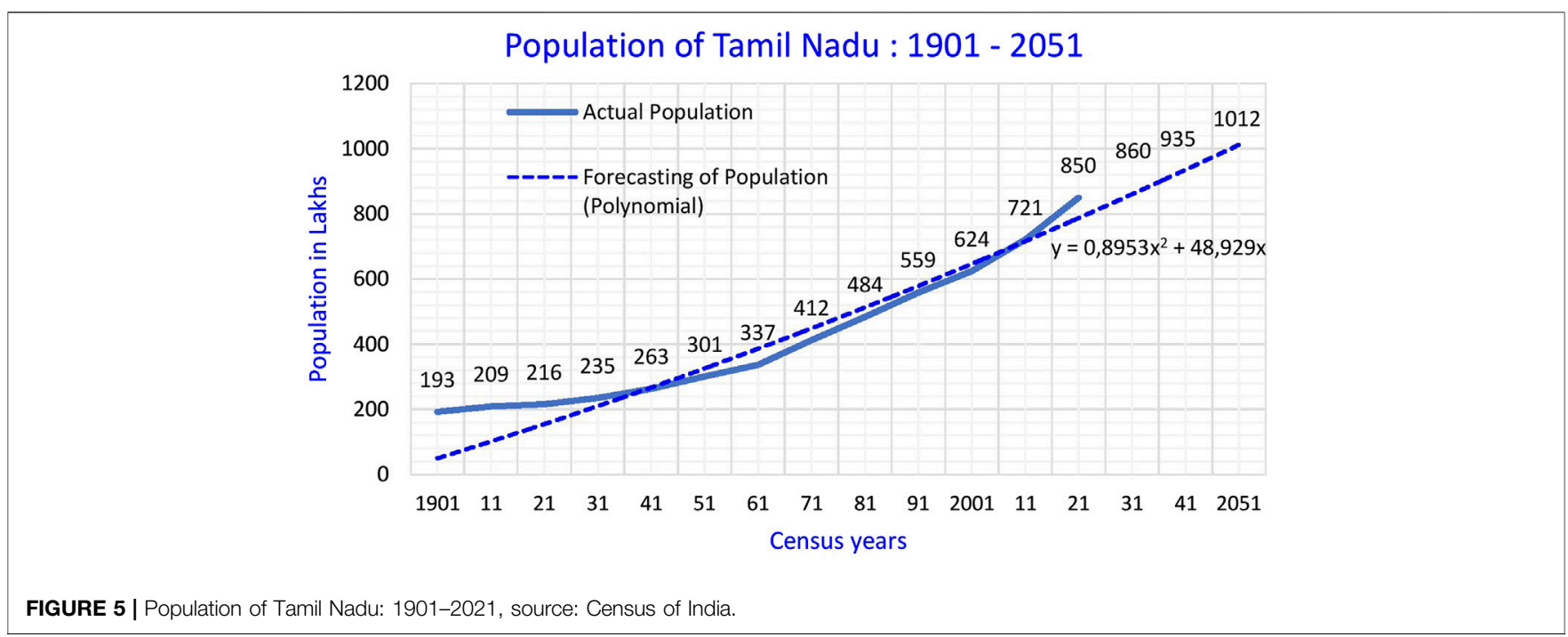


made for urban and rural areas. For urban areas, a 30 years $100 \%$ increase is taken. For rural areas, 30\% was taken. For industrial projections, the annual increase of $8 \%$ was taken into consideration. As far as the livestock are concerned no norms for the increase have been fixed and as per the present requirement are taken for the projection also. From research studies, it was revealed that water needs during 2025 for irrigation, domestic, livestock, and industrial sectors are $55.28,2,1$, and 2.5 billion $\mathrm{m}^{3}$, respectively.

\section{WATER AND CONFLICT}

Resource's scarcity can exacerbate preexisting tensions or invite new ones (Tamas. Pal 2003), and water is no exception. Like the oil shock which the world experienced during the nineteen eighties it would be water shock for the developing countries in the near future, as the population increases steadily bringing down the per capita availability of fresh water as the fresh water resources that are renewed through the global water cycle is a finite natural resource in each country (IPCC, 2014). Access to water is further complicated by conflicts arising over rights to water in river basins shared by countries or by states within a country (Williams et al., 2015). In India the river is still a state subject even though many rivers pass through different states. Coupled with the political process in which a state ruled by a party can be different from the party in power at the Center (India) further complicates river basin management. It would be much prudent to shift the management of the renewable water resources that exist within administrative and political borders, as water is more of a regional resource than a global resource.

\section{WATER RESOURCES DEVELOPMENT: PROJECT PLANNING ON A REGIONAL SCALE}

The central purpose of water resource development is to meet demand and supply. This process involves a detailed assessment of demand both for the present and the future. The natural unit of water resources development is the river basin. Water resources systems were created for the task of matching the supply to the demand for water, in basins or in their sub units. Their traditional form is a group of structures connected through information links; these connect all aspects of supply with all aspects of water demand.

\section{Organizations for Irrigation Management}

Normally, dual-management irrigation systems are developed in a top-down approach. The water users in their "tertiary units" have to follow the technical and institutional innovations made by technicians. Recent rehabilitation programs have not improved irrigation as expected, and water users have not yet become "partners in irrigation management". Good irrigation management appears to be difficult, as conflicting interests are normal in irrigation, and different parties have their own responsibilities.

\section{Management Strategies}

Management strategies must be multifaceted rather than unimodel. It should have macro, micro, and grassroots level planning followed by effective management of catchment (on the upstream side) reservoir and the command (downstream side). The illegal felling of trees and excessive grazing over the catchment besides increasing runoff brings in silt and sediment which ends in surpluses to sea. Optimal catchment treatment would help in a great way in the proper upkeep of the structures created.

The experience in many developing countries has shown that the "fragmented, command-and-control" approach to the management of water resources has failed, both economically and environmentally. Hence, there is a need to use economic incentives and fiscal instruments in achieving economic efficiency in the use of the resource. Furthermore, it is necessary to show that better economic management of this resource will greatly assist in improving the environment. Thus, a policy package is urgently required with a judicious mix of legislation and regulation, including water tariffs, pollution taxes, effluent charges, and groundwater extraction charges, and providing tax benefits or investment support for water conservation and effluent treatment plants.

\section{Water Management Techniques}

Surface water is utilized by scientific methods to the extent possible. Even then, the entire surface water available as surplus is not effectively and economically used, the surplus water (Suresh and Somasundaram, 1996; Suresh 2002) flows into the sea. The T.S. Vijaya Raghavan Committee (The Hindu, 2014) has estimated that from the seven river basins (Figure 2) of Tamil Nadu State, about 76.94 TMC of floodwater is let into the Bay of Bengal in the normal monsoon years. (Figure 6).

To improve the groundwater potential and quality it has been suggested that check dams be constructed across the rivers or surplus waters that could enable water to be diverted to areas in need, where the groundwater table is lower than the sea level. Traditional water management techniques have been neglected or fallen into disuse and are heading to a further decline in water storage capacity and consequently surface water flow into the sea. At present, the coordination between user departments is not up to the required level. The available water sources may be grouped for a river basin and various activities may be monitored. Nothing appreciable is being done to economize water use at present. The difficulties encountered in protecting the installed capacities and loopholes in the system. Tampering by the public, unwillingness to pay for water supply, insufficient qualified staff, paucity of funds, and delegation of powers at various levels may be considered conducive to the present reality.

\section{Rain Water Harvesting in Chennai City, Tamil Nadu}

Chennai is a coastal city, meaning it is always under threat from seawater intrusion along the coast if more freshwater is extracted. For instance, in the Minjure and Mouthambedu well fields located north of Chennai City the fresh groundwater aquifer has been salinized to a length of about $20 \mathrm{KM}$ from the coast with a seawater migration rate of $427 \mathrm{~m}$ per annum-(Natarajan et al., 2017) (Figure 7). Indiscriminate extraction in Minjur, the coastal 
Surplus Water from Tamil Nadu Rivers-2014

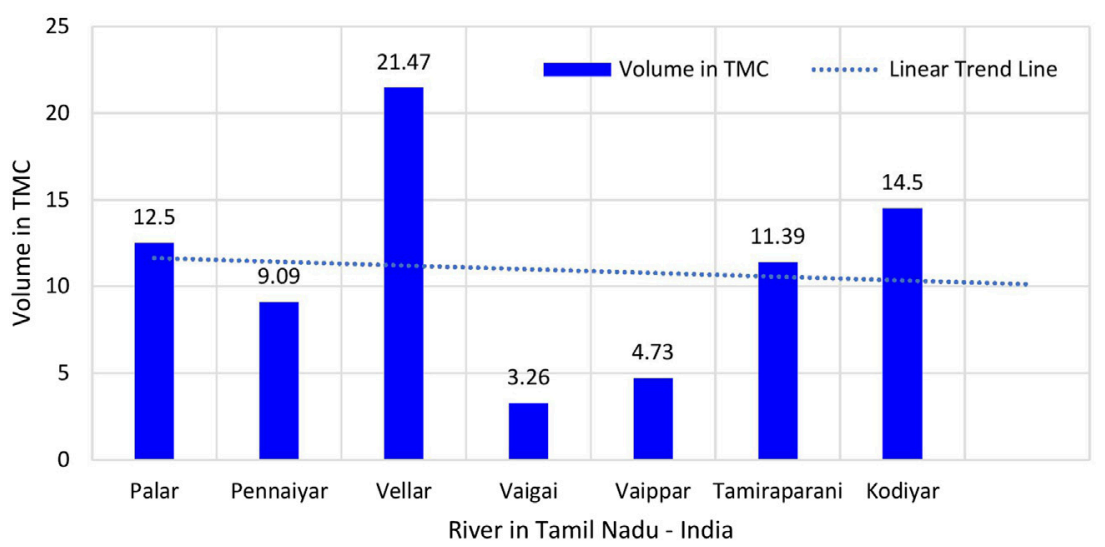

FIGURE 6 | Surplus water from Tamil Nadu river basin. Source: The Hindu (June 23, 2014).

area along the North Sea coast of Chennai has spoiled water because of overexploitation (CGWB 2017).

\section{NATIONAL WATER DEVELOPMENT AGENCY}

This agency has identified that the performance of the existing schemes is insufficient and that the current state of affairs can be improved by modernizing the existing irrigation system, which is dilapidated due to neglect and a lack of maintenance over the years. In most of the systems, the typical problems are an unrealistic and poor distribution of water with tail-enders frequently not getting water and even farmers in the upper reaches getting only unpredictable supply, and that too does not necessarily correspond to the agricultural calendar.

\section{Increasing New Investments in Irrigation}

Although improving the efficiency of existing irrigation schemes is a must, it is still not sufficient to meet the additional requirement for food and fiber in the next 2 decades. Largescale new investments in irrigation schemes will be required for providing adequate food and fiber to meet the objectives of poverty alleviation and development. During the last decade, real investment in irrigation schemes has declined as the cost of new schemes has increased, while the international price of food grains has declined. Given the large contributions required from new schemes, concerted efforts are needed, both at national and international levels, to increase real investments in new irrigation schemes. Many of the delays in the completion of water resource projects often become costly and by the time a revised estimate is sanctioned another price escalation has already taken place.

\section{Water Resources Consolidation Projects}

The prestigious Water Resources Consolidation Project was carried out at an estimated cost of Rs. 1400 crores for remedying the situation. Its main focus is on institutional arrangements, operation and maintenance, planning and management of farmer's participation in water conservation and management, and environmental impact assessment. This project was also undertaken as part of a major revamping of the organizational structure of the Public Works Department (PWD).

\section{CONSERVATION AND RECYCLING-REUSE}

In the domestic sector, the use of water for flushing, bathing, washing, and cleaning can be minimized greatly when conventional taps are replaced by pressure taps where air at relatively high pressure is mixed with water to reduce the quantum water needed. In the industrial sector, a change in the process from water intensive to less water-intensive and finally to cent percent recycling of water could make a difference. In the agriculture sector, efforts to encourage water conservation face special challenges not encountered with other natural resources. In much of the world, water is not controlled by market mechanisms because it is either free or unmetered. Now water is a global resource that can be traded like coal or petroleum. Often, wasting water in one river basin is seen as irrelevant to those who live in another. There is significant scope for water conservation in irrigated agriculture. Higher water rates for water intensive crops such as rice and sugarcane could also encourage farmers a shift towards other crops such as maize, wheat, and barley, etc. Since irrigation charges are generally much lower than the value of water in alternative uses, these low prices do not encourage efficient water use on the farm. Furthermore, efficiency will improve by a more equitable distribution of water between farmers at the head of the distribution system and those at its tail end.

Recycling (desalination) had been tried in coastal districts of Tamilnadu and could be used only for domestic needs (drinking water) in the absence of alternate sources, but the technology available at this date is cost-intensive with the unit cost including depreciation and debt servicing reported from a pilot plant study in 2018-19 of (Rs. 100) \$ 1.3 per 1,000 L Moreover, the disposal of 


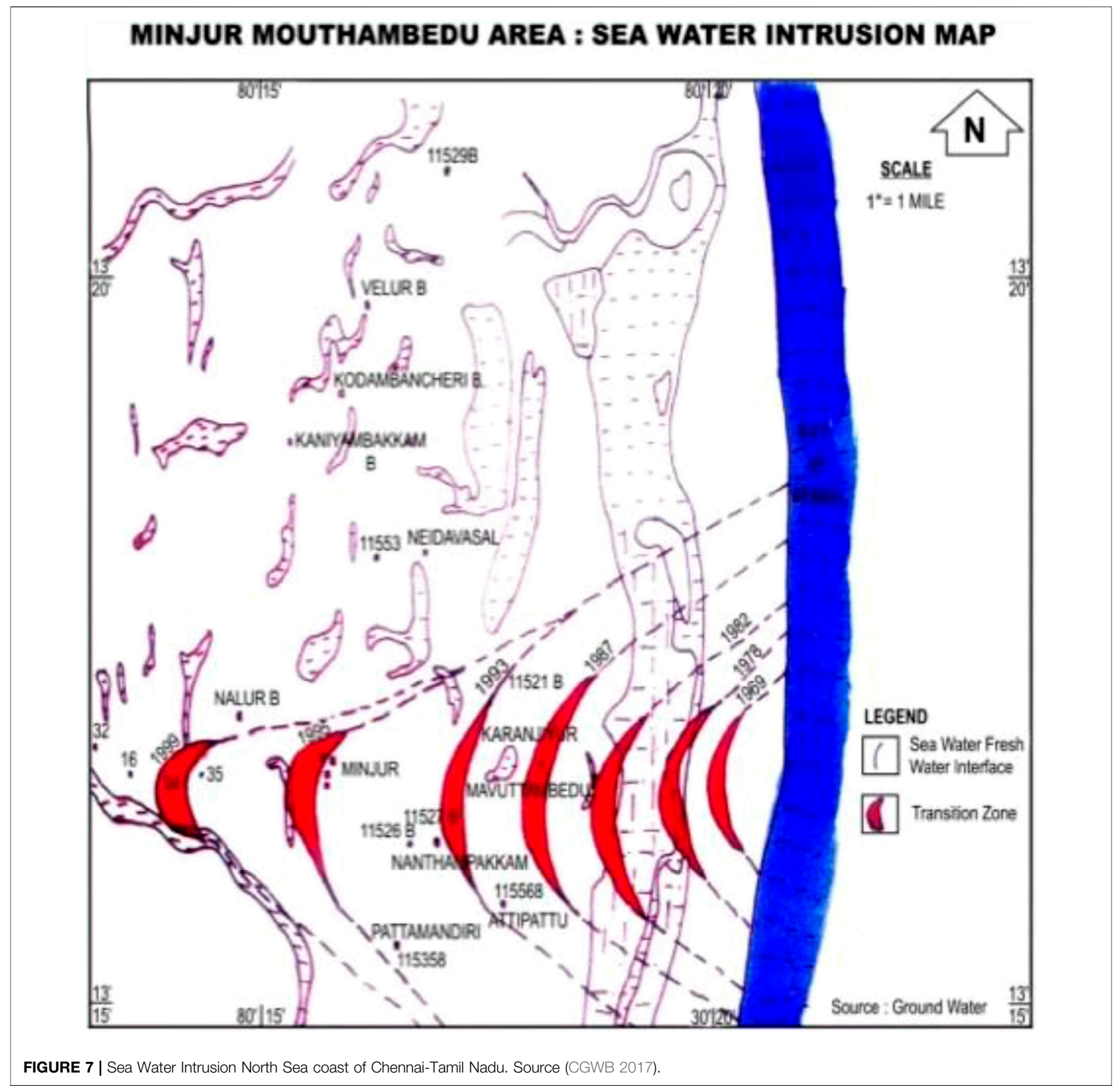

reject water from the desalination plants is a major problem for these plants.

\section{WATER QUALITY-GENERAL OVERVIEW}

Tamil Nadu has limited water resources and draws much for its drinking water schemes from surface, subsurface in riverbeds, and groundwater sources. A large number of water supply schemes draw water from infiltration wells located in major riverbeds. A number of water supply schemes, particularly as regards Urban Town Panchayats (UTPs) and Rural Town
Panchayats (RTPs), draw water from groundwater sources. Approximately 0.15 million bore wells fitted with hand pumps also supply water to the rural public.

\section{Status of Water Quality in Major Municipal Water Supply Schemes}

An analysis of data reveals that fluoride, nitrate, iron, and Total Dissolved Solids (TDS) are the critical chemical parameters that noticeably influence water quality (Sivasankar et al., 2012). The Tamil Nadu districts of Dharmapuri, Salem, and Periyar are severely affected by fluoride. The districts of Coimbatore, 
Madurai, Virudhunagar, and Tuticorin are also affected to some level. In Dharmapuri District about 54\% of the sources are found to be not potable either in one season or another season. High seasonal variation renders the same water sources as potable in one season and not potable in another season. Approximately $10 \%$ of the sources in Dharmapuri, Salem, and Erode have high fluoride levels of greater than $3 \mathrm{mg} / \mathrm{L}$. Special attention is needed in these districts to avoid the problem of skeletal flourish. Cases of skeletal flourish have already been reported in Salem District. The level of Nitrate in most of the groundwater sources is becoming a problem and it has been noted in most of the districts. In the northwestern parts of Tamilnadu, it is above $60 \%$. Increased agriculture activities and the application of fertilizers may be attributed to this phenomenon. Parts of the northern districts are affected by the high level of iron in the water. It has been observed that the iron content in any source generally decreases with continuous use.

High seasonal variation is noted in the level of TDS in groundwater sources in Tamilnadu. In Coimbatore about $90 \%$ of the water sources become non-potable for no specific season. With respect to groundwater sources, it is difficult to separately demarcate the saline areas in the state. The level of TDS depends on the water level and the depth of the well in various places. Certain pockets in the districts of Ramanathapuram (Sivasankar et al., 2012), Tuticorin, Pudukottai, and Coimbatore have a TDS of more than $3,000 \mathrm{mg} / \mathrm{L}$. In these areas where water quality is a limiting factor, a change of source or treatment of water to bring it into a form suited for drinking purposes is required. Rainwater harvesting on rooftops and construction of percolation ponds (Figure 8) would result in diluting the groundwater by direct recharge and thus result in the portability of water.

\section{Factors Affecting Water Quality in Tamilnadu}

In Tamil Nadu, there are about 4,820 highly polluting industries, which are called RED category industries. It has also been

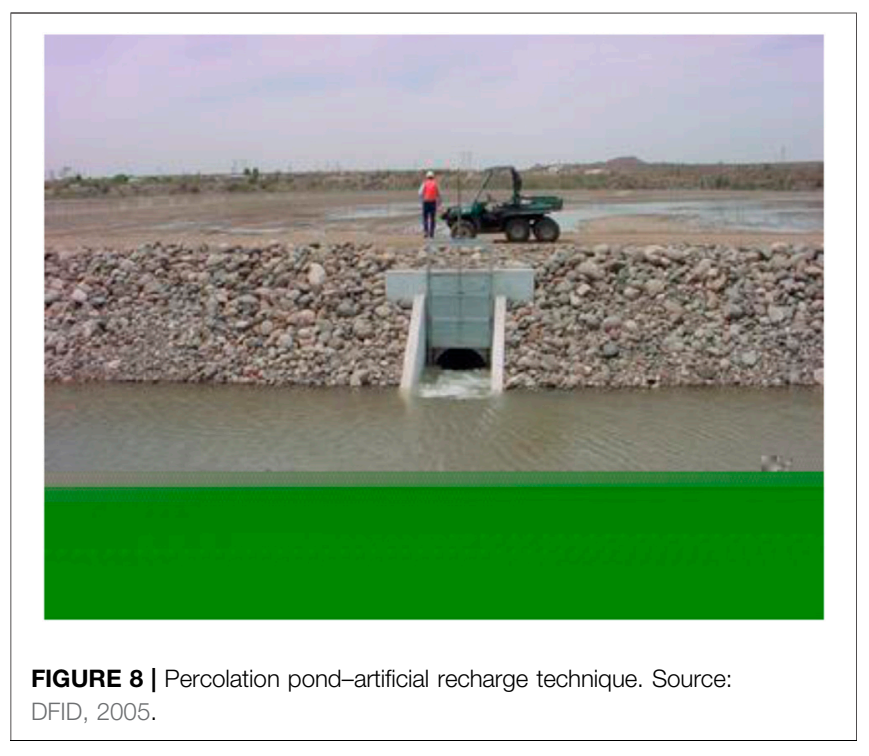

reported that out of the 5,059 industries listed as requiring effluent treatment plants, only 1,114 industries have provided the same type of effluent treatment plant. The impact of tannery pollution in the Palar river basin is in alarming proportion. The tannery effluent having high BOD, Sodium chloride, and chromium are let into the Palar river which takes water from infiltration wells is having high TDS, contrary to the expected quality for subsurface water in the river bed. High salinity is also noted in open well and bore well sources in Vaniyabadi, Ambur, Ranipet, Wallajah, and other towns in Tiruvannamalai, Vellore, Ranipet, and Tirupathur district. Dindigul is another district, which is severely affected by tannery pollution. Due to the depletion of present water sources and lowering of water levels in many of the bore wells, it is noted that the groundwater quality is severely affected. It is natural that when the groundwater level decreases the traveling time and contact time of water through soil increases and thus carries more salt with it.

\section{CONCLUSION}

Over exploitation of groundwater, which is frequently used and transported for urban uses indiscriminately can be easily checked if land policies are framed for fragmentation and subdivision, pricing of electricity, limiting the use and spacing of deep bore rigs, and the long-awaited groundwater legislation. From the research study, it was revealed that an increase in 10-15 per cent of water use efficiency in the agriculture sector would result in sufficient water availability for urban and industrial uses without sacrificing food production. Drinking water (less than 4 per cent of agriculture water use), which is of the highest priority, should be supplied through pipelines to the tail and reaches of the river basins (Ramanathapuram district in Vaigai basin) from existing reservoir schemes rather than using the local groundwater beyond the recharging limits.

Livestock reared by almost every household in rural areas are slowly disappearing as many of the cattle are sent to neighboring Kerala state for slaughter (cow slaughtering is banned in the Hindu region). Furthermore, several commercial ventures have come up recently adding to the concentration of livestock population, commercial cultivation of fodder, and thereby bringing in pressures on scarce water resources. This is of serious note, as a pair of bullocks/cows/goats form a symbiotic and synergistic relationship with the farming community leading to sustainable agriculture, but commercialization has resulted in a greater shift from the existing practices. Efforts in the form of loans and other incentives should be given to encourage small livestock holdings.

Increased investment in wastewater treatment and reuse could yield good returns as the marginal cost of treatment, storage, and conveyance of purified wastewater for agriculture use will be only $\$ 0.13 / \mathrm{m}^{3}$. The introduction of tradable water rights will help move the water from less productive to more productive use. Farmers could also sell their water rights to the non-agriculture sector thus making the irrigation systems more competitive and challenging. Recently a neighboring Kerala state had ventured into an issue of bonds to raise capital for 
implementing water projects. Such a venture could help to boost the morale of the public and encourage them to invest in developmental projects.

To increase the level of coordination between various sectors and implement projects in time and full commitment, a hierarchy of irrigation cooperatives should be formed at different levels with user participation for the operation and maintenance of systems. The placement of water issues in the top five of their manifestos to choose a political party to form the government is also a welcome sign in raising the water consciousness of people. In this regard, the concept of Built Operate and Transfer (BOT) or the Turn over the system, has already proved successful in minor irrigation schemes (Tank projects) and could present a solution for conflicts between users as opposed to uses. If minor changes are made in improving irrigation efficiency, reducing effluent discharges, and increasing the reuse of water in all sectors, they could help solve water problems and bring prosperity in the foreseeable future.

\section{DATA AVAILABILITY STATEMENT}

The datasets presented in this study can be found in online repositories. The names of the repository/repositories and accession number(s) can be found in the article/Supplementary Material.

\section{ETHICS STATEMENT}

Ethical review and approval was not required for the study on human participants in accordance with the local legislation and institutional

\section{REFERENCES}

Bitterman., P., Eric., T., Itimberly, J., Van, M., and Nandita, B. B. (2016). Water Security and Rainwater Harvesting: A Conceptual Framework and Candidate Indicators. Appl. Geogr. 76, 75-84.

Chitra, M., and Laxmi, K. B. (2017). An Analysis on Supply of Water in Tamil Nadu. Shanlax Int. J. Econ. 5 (3), 48-54. Available at: https://www. researchgate.net/publication/331772076_An_Analysis_on_Supply_of_Water_ in_Tamil_Nadu.

Census of India (2011). Census of India. Available at: https://censusindia.gov.in/ 2011-prov-results/data_files/tamilnadu/3.Tamil\%20Nadu_PPT_2011-BOOK $\% 20$ FINAL.pdf.

Cgwb (2000). CGWB. Available at: http://cgwb.gov.in/documents/ArtificialRechargeGuide.pdf.

Cgwb (2017). CGWB. Available at: http://cgwb.gov.in/AQM/NAQUIM_REPORT/ TAMILNADU/chennai\%20Aquifer\%20system.pdf.

Corporation of Tamil Nadu (2020). Corporation of Tamil Nadu. Available at: https://en.wikipedia.org/wiki/List_of_municipal_corporations_in_ Tamil_Nadu.

DFID (2005). Engineering Knowledge and Research Programme: Water Demand Management in the Areas of Ground Water over Exploitation, A Report on Case Studies. Available at: https://assets. publishing.service.gov.uk/media/57a08c6b40f0b652dd0012fe/R8332-Case Stud.pdf.173

ENVIS (2020). Envis center: Tamil Nadu State Environmental and Related Issues. Available at: http://tnenvis.nic.in/Database/Industries_1167.aspx.

Glendenning, C. J., van Ogtrop, F. F., Mishra, A. K., and Vervoort, R. W. (2012). Balancing Watershed and Local Scale Impacts of Rain Water Harvesting in requirements. Written informed consent to participate in this study was provided by the participants' legal guardian/next of kin.

\section{AUTHOR CONTRIBUTIONS}

The author confirms being the sole contributor of this work and has approved it for publication.

\section{ACKNOWLEDGMENTS}

The author sincerely thanks the reviewers and Professor Shafi Mohammad Tareq for reviewing this manuscript. The author thank his daughter Akshaya Suresh, XII Class student, Cluny Matriculation Higher Secondary School, Salem-7, Tamil Nadu and his wife K. Sathia Meena, Assistant Professor, Government College of Arts, Salem-7, Tamil Nadu for their support to write this manuscript. This paper is dedicated to the fond memory of the author's Master degree guide, (Late) Dr. M.V. Somasundaram, Professor and Scientist ' $F$ ' and his master degree professor in-charge (Late) Dr. S. Thayumanavan at Centre for Water Resources, College of Engineering, Guindy, Anna University, Chennai-600025, Tamil Nadu, India.

\section{SUPPLEMENTARY MATERIAL}

The Supplementary Material for this article can be found online at: https://www.frontiersin.org/articles/10.3389/feart.2021.663198/ full\#supplementary-material

India-A Review. Agric. Water Management 107, 1-13. doi:10.1016/ j.agwat.2012.01.011

Gollin, D., Parente, S., and Rogerson, R. (2002). The Role of Agriculture in Development. Am. Econ. Rev. 92 (2), 160-164. doi:10.1257/000282802320189177 ICID (2018). International Commission of Irrigation and Drainage (ICID), 48 Nyaya Marg. New Delhi: Chanakyapuri, 110021. Available at: https://www.icid. org/world-irrigated-area.pdf.

Municipality of Tamil Nadu (2020). Municipality of Tamil Nadu. Available at: https://tnrd.gov.in/databases/tn_municipality_details.pdf.

Natarajan, P. M., Ponnavaiko, M., Kalloikar, S., Rangaraju, G., and Ganesh, S. (2017). Sustainable Water Resources Development in Tamil Nadu India through Water Security Pathways. XVI World Water Congress, 1-19. Available at: https://iwra. org/member/congress/resource/ABSID139_ABSID139_WWC_1.pdf.

National Water Mission (20172017). State/UT Specific Action Plans (SSAP) on Water: Towards Water Security, Safety and Sustainability. Available at: http:// nwm.gov.in/sites/default/files/SSAP\%2029.10.2017\%20with\%20headnote.pdf. 443445

Pal Tamas (2003). Water Resource Scarcity and Conflict: Review of Applicable Indicators and Systems of referenceTechnical Documents in Hydrology: PC-CP Series, SC.2003/WS/49, 1-37. Available at: https://unesdoc.unesco.org/ark:/ $48223 / \mathrm{pf0000133307.}$

IPCC (2014). in Climate Change 2014: Synthesis Report, Contribution of Working Groups, I, II and III to the Fifth Assessment Report of Intergovernmental Panel on Climate Change [Core Writing Team. Editors R. K. Pachauri and L. A. Meyer (Geneva, Switzerland: IPCC), 1-151. Available at: https://www.ipcc.ch/site/assets/uploads/2018/05/SYR_AR5_FINAL_full_ wcover.pdf

Ruttan, V. W. (1965). Growth Stage Theories and Agricultural Development Policy*. Aust. J. Agric. Econ. 9, 17-32. doi:10.1111/j.1467-8489.1965.tb00327.x 
S, M., and N, R. (2014). Climate Change and its Impact on Irrigation Water Requirements on Temporal Scale. Irrigat Drainage Sys Eng. 03 (118), 2-10. doi:10.4172/2168-9768.1000118

Sivasankar, V., Ramachandramoorthy, T., and Chandramohan, A. (2012). Deterioration of Coastal Groundwater Quality in Island and mainland Regions of Ramanathapuram District-Southern India. Environ. Monit. Assess. 185, 931-944. doi:10.1007/s10661-012-2604-2

State of Indian Agriculture (2016). State of Indian Agriculture. Available at: https:// agricoop.nic.in/sites/default/files/State_of_Indian_Agriculture\%2C2015-16.pdf.

Statistical Hand Book (2016). Statistical Hand Book. Availableat: https://cdn. s3waas.gov.in/s313f3cf8c531952d72e5847c4183e6910/uploads/2018/06/2018 062923.pdf.

Suresh, C. A., and Surender, K. (2011). "Challenges and Implications for Water Pricing Industrial Water Demand in India," in the India Infrastructure Report 2011, 274-281. Available at: https://www.idfc.com/pdf/report/2011/Chp-18Industrial-Water-Demand-in-India-Challenges.pdf.

Suresh, S., and Somasundaram, M. V. (1996). Towards a Comprehensive Water Policy for India with Special Reference to Tamil Nadu. Sixth Stockholm Water Symposium, Stockholm, Sweden 277-279. Available at: https://www.ircwash.org/resources/safeguarding-water-resources-tomorrownew-solutions-old-problems-proceedings-sixth.

Suresh, S. (2002). Sustainability of Integrated Water Resources Management in Indian River Basin with Special Reference to Flood. Second Int. Symp. Flood Defence (Isfd'2002) Beijing 1, 382-388. Available at: http://www.irtces.org/nszx/ $\mathrm{zt} / \mathrm{issh}$ u/isfd10.htm\#Volume\%20I.
The Hindu (2014). The Hindu. Available at: https://www.thehindu.com/archive/ web/2014/06/23/.

Vairavamoorthy, K., Gorantiwar, S. D., and Mohan, S. (2007). Intermittent Water Supply under Water Scarcity Situations. Water Int. 32 (1), 121-132. doi:10.1080/02508060708691969

Williams, R. B., and Al-Hmoud, R. (2015). Virtual Water on the Southern High Plains of Texas: The Case of a Nonrenewable Blue Water Resource. Nr 06 (1), 27-36. doi:10.4236/nr.2015.61004

Conflict of Interest: The author declares that the research was conducted in the absence of any commercial or financial relationships that could be construed as a potential conflict of interest.

Publisher's Note: All claims expressed in this article are solely those of the authors and do not necessarily represent those of their affiliated organizations, or those of the publisher, the editors and the reviewers. Any product that may be evaluated in this article, or claim that may be made by its manufacturer, is not guaranteed or endorsed by the publisher.

Copyright $\odot 2021$ Suresh. This is an open-access article distributed under the terms of the Creative Commons Attribution License (CC BY). The use, distribution or reproduction in other forums is permitted, provided the original author(s) and the copyright owner(s) are credited and that the original publication in this journal is cited, in accordance with accepted academic practice. No use, distribution or reproduction is permitted which does not comply with these terms. 